\title{
NOTE
}

\section{Regulatory Effect of Endogenous Calcitonin on Calcium Metabolism in Hepatic Bile System of Rats}

\author{
Masayoshi YAMAGUCHI \\ Department of Environmental Biochemistry, Shizuoka College of \\ Pharmacy, 2-2-1, Oshika, Shizuoka 422, Japan
}

\begin{abstract}
The effect of calcium chloride $\left(4.0 \mathrm{mg} \mathrm{Ca}^{2+} / 100 \mathrm{~g} \mathrm{BW}\right)$ on the calcium metabolism in the hepatic bile system was investigated in intact and thyroparathyroiđectomized rats. The administration of calcium did not alter the serum calcium of intact rats but increased it markedly in thyroparathyroidectomized rats. The administration of calcium to intact rats also caused a significant decrease in the liver plasma membrane Ca-ATPase activity, and a corresponding increase in liver calcium and bile calcium, while no such increase was seen in thyroparathyroidectomized rats. Meanwhile, the administration of calcitonin $(\mathrm{CT}, 80 \mathrm{MRC} \mathrm{mU} / 100 \mathrm{~g} \mathrm{BW})$ to intact rats significantly lowered both serum calcium and liver plasma membrane Ca-ATPase activity, and it also significantly elevated both liver and bile calcium. These results suggest that endogenous CT regulates calcium metabolism in the hepatic bile system of rats after the injection of calcium chloride.
\end{abstract}

It is well known that calcitonin (CT) causes the inhibition of bone resorption (Johnston et al., 1966). CT also excludes excess calcium from the serum by an action which is attributed to a reduction in intestinal calcium absorption (Olson et al., 1972) and an increase in urinary calcium excretion (Haas et al., 1971) due to the hormone. Thus the effect of CT on serum calcium plays an important role in the regulation of calcium homeostasis. Recently it has been found that CT acts on calcium metabolism in the pool of hepatic bile in rats. CT causes an increase of calcium accumulation in rat liver (Yamaguchi et al., 1975; Yamaguchi, 1978) and stimulates the excretion of calcium into rat bile (Yamaguchi and Yamamoto, 1978 and 1979). It is possible that the action of CT on the bile pool of the hepatocyte plays a part in the control of calcium metabolism. The present study was therefore undertaken to exmine whether calcium metabolism in the hepatic bile system of rats is regulated by endogenous CT.

\section{Materials and Methods}

Animals

Male Wistar rats, weighing approximately 100 $120 \mathrm{~g}$, were used. They were obtained commercially from the Nippon Bio Supp. Center, Tokyo, Japan. The animals were fed commercial lab. chow containing $1.1 \% \mathrm{Ca}$ and $1.1 \% \mathrm{P}$ (Oriental Test Diet, Tokyo, Japan) and tap water freely.

\section{Hormone}

Calcium chloride was dissolved in sterile, demineralized water. Calcitonin (porcine CT, $68 \mathrm{MRC}$ U/mg, Armour Pharmaceutical Company, Kankakee, IIl., U.S.A) was dissolved in sterile, demineralized water. The vehicle was injected as control. 


\section{Experimental procedures}

The thyroparathyroid gland complex was removed with fine forceps under light ether anesthesia. Under intraperitoneal $25 \%$ urethane anesthesia $(0.6 \mathrm{ml} / 100 \mathrm{~g}$ BW) $24 \mathrm{hr}$ after thyroparathyroidectomy (TPTX), the abdomen was opened by a midline incision. The bile duct was then cannulated with PE-10 tubing which was secured in place, and then the incision was closed with wound clips. The animals were put on a warm water bath $\left(38 \pm 1^{\circ} \mathrm{C}\right)$ to maintain body temperature (Robert et al., 1967), and bile was collected. The rats were not fed or given water. Calcium chloride was then administered at the midpoint of the abdomen. Immediately after calcium administration, CT was administered at a separate site. The administration of calcium chloride $(4.0 \mathrm{mg}$ $\mathrm{Ca}^{2+} / 0.5 \mathrm{ml} / 100 \mathrm{~g} \mathrm{BW}$ ) was done intraperitoneally, and

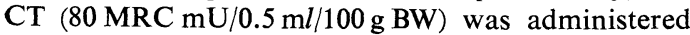
subcutaneously. The rats were bled by cardiac puncture $30 \mathrm{~min}$ after $\mathrm{CT}$ administration.

\section{Analytical methods}

Blood samples obtained by cardiac puncture were centrifuged immediately after collection. The serum was separated and analyzed immediately. Determination of calcium was made on $0.1 \mathrm{ml}$ aliquots of serum by atomic absorption spectrophotometry (Perkin-Elmer, Model 303) after precipitation with $10 \%$ trichloroacetic acid (Willis, 1960).

Liver was removed immediately after bleeding and perfused with cold $0.25 \mathrm{M}$ sucrose solution to remove the blood. The amount of calcium in the liver was determined utilizing atomic absorption spectrophotometry after nitric acid digestion.

The liver plasma membrane fraction was prepared according to the procedure of Forte et al. (1973), as previously described (Yamaguchi, 1979). To assay for Ca-ATPase activity, the reaction mixture contained, in a final volume of $1.5 \mathrm{ml}, 30 \mathrm{mM}$ Tris- $\mathrm{HCl}$ buffer ( $\mathrm{pH} 7.4$ ), $10 \mathrm{mM} \mathrm{CaCl}_{2}, 5 \mathrm{mM}$ ATP and liver plasma membrane protein $(150-200 \mu \mathrm{g})$. Incubation were carried out in a water-bath at $37^{\circ} \mathrm{C}$ for $10 \mathrm{~min}$ during which time the reaction was linear. The reaction was then stopped by quickly placing the tubes in an ice-bath and adding $1 \mathrm{ml} 15 \%$ (w/v) $\mathrm{HClO}_{4}$. ATP hydrolysis was measured by the release of inorganic phosphate as determined by the method of Nakamura and Mori (1958). Protein was determined by the method of Lowry et al. (1951). $\mathrm{Ca}$-ATPase activity was expressed as nmoles $\mathrm{Pi}$ released per min per $\mathrm{mg}$ protein.

The bile was collected for $30 \mathrm{~min}$ after $\mathrm{CT}$ administration and the volume measured by means of a pipette graduated in $0.01 \mathrm{~m} l$. The amount of bile calcium was determined by atomic absorption spectrophotometry. The bile calcium was expressed as the excreted calcium $(\mu \mathrm{g})$ per $100 \mathrm{~g}$ body weight of rats.
Table 1. Effect of calcium chloride or calcitonin on the serum calcium concentration in intact and thyroparathyroidectomized (TPTX) rats.

\begin{tabular}{lccc}
\hline \multirow{2}{*}{ Treatment } & \multirow{2}{*}{$\begin{array}{c}\text { Number } \\
\text { of rats }\end{array}$} & \multicolumn{2}{c}{$\begin{array}{c}\text { Serum calcium } \\
(\mathrm{mg} / 100 \mathrm{~m} l)\end{array}$} \\
\cline { 3 - 4 } & & Intact rats & TPTX rats \\
\hline Control & 5 & $9.9 \pm 0.21$ & $6.7 \pm 0.22$ \\
Calcium & 5 & $10.2 \pm 0.29$ & $10.1 \pm 0.40 \mathrm{a}$ \\
Calcitonin & 5 & $8.2 \pm 0.23 \mathrm{a}$ & $5.8 \pm 0.20 \mathrm{a}$ \\
$\begin{array}{l}\text { Calcium }+ \\
\text { calcitonin }\end{array}$ & 6 & $7.7 \pm 0.13 \mathrm{a}, \mathrm{b}$ & $7.3 \pm 0.38 \mathrm{~b}$ \\
\hline
\end{tabular}

Values are mean \pm SE. Calcium chloride $(4.0 \mathrm{mg}$ $\mathrm{Ca}^{2+} / 100 \mathrm{~g} \mathrm{BW}$ ) was administered intraperitoneally $24 \mathrm{hr}$ after thyroparathyroidectomy, and immediately calcitonin ( $80 \mathrm{MRC} \mathrm{mU} / 100 \mathrm{~g} \mathrm{BW}$ ) was administered subcutaneously. The rats were bled $30 \mathrm{~min}$ after the injection of the hormone.

a. $\mathbf{P}<0.01$ as compared with control group.

b. $\mathbf{P}<0.01$ as compared with calcium-treated group.

\section{Statistical methods}

The data were subjected to an analysis of variance, and standard error (SE) was calculated from the residual error term. Statistical significance is expressed as $\mathbf{P}$ values from Student's $t$ test.

\section{Results}

The effect of calcium chloride or calcitonin (CT) on the serum calcium concentration in intact and thyroparathyroidectomized rats is shown in Table 1 . The administration of calcium chloride $(4.0 \mathrm{mg}$ $\left.\mathrm{Ca}^{2+} / 100 \mathrm{~g} \mathrm{BW}\right)$ to intact rats did not significantly increase the serum calcium concentration, while it was markedly enhanced in thyroparathyroidectomized rats. Meanwhile, the administration of CT $(80$ MRC mU/100 g BW) to intact or thyroparathyroidectomized rats significantly decreased the serum calcium concentration. The administration of both calcium chloride (4.0 $\mathrm{mg} \mathrm{Ca}{ }^{2+} / 100 \mathrm{~g} \mathrm{BW}$ ) and CT (80 MRC $\mathrm{mU} / 100 \mathrm{~g} \mathrm{BW})$ to intact or thyroparathyroidectomized rats markedly reduced the serum calcium concentration in comparison with 
Table 2. Effect of calcium chloride or calcitonin on Ca-ATPase activity in the liver plasma membrane of intact and thyroparathyroidectomized (TPTX) rats.

\begin{tabular}{lccc}
\hline Treatment & $\begin{array}{c}\text { Number } \\
\text { of rats }\end{array}$ & \multicolumn{2}{c}{$\begin{array}{c}\text { Ca-ATPase } \\
\text { (nmol/min/mg protein) }\end{array}$} \\
\hline Intact rats & TPTX rats \\
\hline Control & 5 & $108.4 \pm 8.4$ & $61.4 \pm 1.1$ \\
Calcium & 5 & $69.4 \pm 1.4 \mathrm{a}$ & $65.1 \pm 3.4$ \\
Calcitonin & 5 & $68.2 \pm 5.6 \mathrm{a}$ & $62.0 \pm 2.0$ \\
$\begin{array}{c}\text { Calcium+ } \\
\text { calcitonin }\end{array}$ & 6 & $68.0 \pm 2.6 \mathrm{a}$ & $60.8 \pm 2.8$ \\
\hline
\end{tabular}

Values are mean \pm SE. Calcium chloride $(4.0 \mathrm{mg}$ $\mathrm{Ca}^{2+} / 100 \mathrm{~g} \mathrm{BW}$ ) was administered intraperitoneally $24 \mathrm{hr}$ after thyroparathyroidectomy, and immediately calcitonin (80 MRC mU/100 $\mathrm{g} \mathrm{BW}$ ) was administered subcutaneously. The rats were bled $30 \mathrm{~min}$ after the injection of the hormone.

a. $\mathbf{P}<0.01$ as compared with control group.

that of calcium-treated rats.

The effect of calcium chloride or CT on Ca-ATPase activity in the liver plasma membrane fraction is shown in Table 2. Ca-ATPase activity in intact rats was markedly lowered by the administration of calcium chloride, while it was not significantly altered in thyroparathyroidectomized rats. The administration of CT to intact rats produced a remarkable reduction in Ca-ATPase activity. However, the administration of both calcium chloride and CT to intact rats did not significantly change Ca-ATPase activity in comparison with that of calcium-treated rats. Meanwhile, thyroparathyroidectomy caused a marked reduction in Ca-ATPase activity. The administration of $\mathrm{CT}$, or both calcium chloride and CT to thyroparathyroidectomized rats did not significantly alter $\mathrm{Ca}$ ATPase activity.

The effect of calcium chloride or CT on the liver calcium contents is shown in Table 3. The administration of calcium chloride, CT, or both calcium chloride and CT to intact rats significantly elevated the liver calcium content. In thyroparathyroidectomized rats, the liver calcium content
Table 3. Effect of calcium chloride or calcitonin on the liver calcium content in intact and thyroparathyroidectomized (TPTX) rats.

\begin{tabular}{lccc}
\hline Treatment & \multirow{2}{*}{$\begin{array}{c}\text { Number } \\
\text { of rats }\end{array}$} & \multicolumn{2}{c}{$\begin{array}{c}\text { Liver calcium } \\
\mu \mathrm{g} / \mathrm{g} \text { wet tissue })\end{array}$} \\
\cline { 3 - 4 } Control & 5 & $14.9 \pm 1.0$ & $16.8 \pm 0.7$ \\
Calcium & 5 & $18.7 \pm 1.2 \mathrm{a}$ & $18.3 \pm 1.4$ \\
Calcitonin & 5 & $20.2 \pm 1.5 \mathrm{a}$ & $20.8 \pm 1.1 \mathrm{a}$ \\
$\begin{array}{c}\text { Calcium }+ \\
\text { calcitonin }\end{array}$ & 6 & $22.6 \pm 1.6 \mathrm{a}$ & $24.3 \pm 1.4 \mathrm{a}, \mathrm{b}$ \\
\hline
\end{tabular}

Values are mean \pm SE. Calcium chloride $(4.0 \mathrm{mg}$ $\left.\mathrm{Ca}^{2+} / 100 \mathrm{~g} \mathrm{BW}\right)$ was administered intraperitoneally $24 \mathrm{hr}$ after thyroparathyroidectomy, and immediately calcitonin ( $80 \mathrm{MRC} \mathrm{mU} / 100 \mathrm{~g} \mathrm{BW}$ ) was administered subcutaneously. The rats were bled $30 \mathrm{~min}$ after the injection of the hormone.

a. $\mathbf{P}<0.01$ as compared with control group.

b. $\mathbf{P}<0.01$ as compared with calcium-treated group.

was not significantly changed by the administration of calcium chloride, while CT, or both calcium chloride and CT increased it significantly as compared with the control group. The administration of both calcium chloride and CT to thyroparathyroidectomized rats significantly increased the liver calcium content when compared with that of calcium-treated rats.

The effect of calcium chloride or CT on the bile calcium content is shown in Fig. 1. The administration of calcium choloride to intact rats markedly increased the bile calcium content, while it was not significantly elevated in thyroparathyroidectomized rats. The administration of CT to intact or thyroparathyroidectomized rats significantly increased the bile calcium content. The administration of both calcium chloride and $\mathrm{CT}$ to thyroparathyroidectomized rats markedly $(\mathrm{P}<0.01)$ increased the bile calcium content in comparison with that of control or calcium-treated rats. 


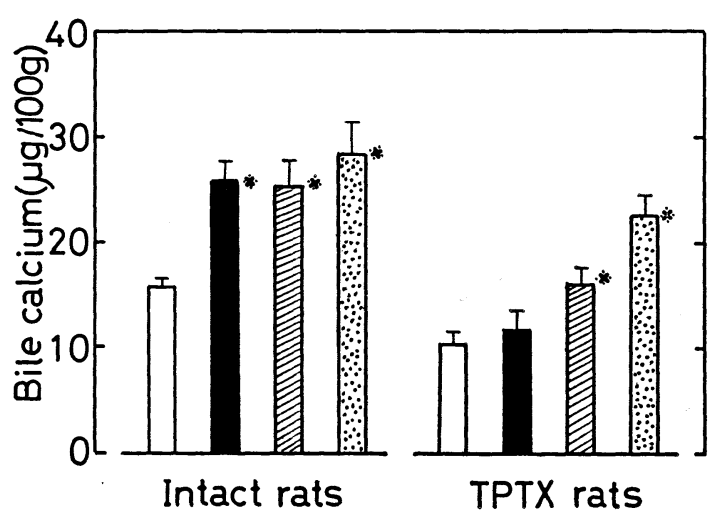

Fig. 1. Effect of calcium chloride or calcitonin on the bile calcium content in intact and thyroparathyroidectomized (TPTX) rats. Calcium chloride (4.0 $\mathrm{mg} \mathrm{Ca}^{2+} / 100 \mathrm{~g} \mathrm{BW}$ ) was administered intraperitoneally to rats the bile ducts of which were cannulated $24 \mathrm{hr}$ after thyroparathyroidectomy, and immediately calcitonin ( $80 \mathrm{MRC} \mathrm{mU} / 100 \mathrm{~g} \mathrm{BW}$ ) was administered subcutaneously. The bile was collected for $30 \mathrm{~min}$ after the injection of the horm one. Each bar represents the mean value for 5 or 6 rats. The horizonal lines give the SE.

*; $\mathrm{P}<0.01$ as compared with control group.

**; $\mathrm{P}<0.01$ as compared with calcium-treated group.

$\square$; control, $\square$; calcium, $\mathbb{E}$; calcitonin, $\because 3$; calcium + calcitonin.

\section{Discussion}

It is well known that calcitionin (CT) has a hypocalcemic effect which is reportedly attributed to the inhibition of bone resorption (Johnston et al., 1966), the reduction in intestinal calcium absorption (Olson et al., 1972), and the increase in urinary calcium excretion (Haas et al., 1971) by the hormone. Recently it has been shown that the excretion of calcium into the bile is increased by the elevation of serum calcium, and that CT markedly increased bile calcum excretion in rats (Yamaguchi and Yamamoto, 1978). The increase in bile calcium excretion produced by $\mathrm{CT}$ is attributable to the augmentation of liver calcium accumulation caused by the hormone (Yamaguchi, 1978). More re- cently it has been reported that the action of CT on liver calcium accumulation involves a decrease in Ca-ATPase activity in the plasma membrane of rat liver (Yamaguchi, 1979). Thus it has been demonstrated that exogenous CT affects calcium metabolism in the pool of hepatic bile of rats. However, the effect of endogenous CT on the hepatic bile calcium has not been fully clarifid.

In the present studids, the effect of endogenous CT on the serum calcium level, the liver plasma membrane Ca-ATPase activity, the liver calcium content, and the bile calcim excretion was examined $30 \mathrm{~min}$ after a single intraperitoneal administration of calcium chloride $\left(4.0 \mathrm{mg} \mathrm{Ca}{ }^{2+} / 100 \mathrm{~g} \mathrm{BW}\right)$ to intact and thyroparathyroidectomized rats. The serum calcium was not significantly increased by the administration of calcium chloride to intact rats, while it was markedly elevated in thyroparathyroidectomized rats, suggesting that the serum calcium level is regulated by the endogenous CT. In fact, CT is secreted from the thyroid gland by the elevation of serum calcium after the administration of calcium chloride to rats (Broulik and Pocorsky, 1973). Furthermore, the administration of calcium chloride caused a significant fall in liver plasma membrane Ca-ATPase activity, and a corresponding increase in both liver and bile calcium of intact rats but not of thyroparathyroidectomized rats. From the present results, it is suggested that the endogenous CT acts on the calcium metabolism in the bile pool of the hepatocyte in rats.

The administration of CT to thyroparathyroidectomized rats did not cause a significant decrease in Ca-ATPase activity in the liver plasma membrane fraction, perhaps because of the lower initial enzyme activity in thyroparathyroidectomized rats. However, the liver calcium and the bile calcium excretion were significantly increased by $\mathrm{CT}$ administration. These results 
suggested that $\mathrm{CT}$ stimulates the influx of calcium into the liver cells, since Ca-ATP ase in the plasma membrane of cells is involved in the energy-dependent pathway for calcium efflux (Moore et al., 1974; Chambaut et al., 1974). CT markedly decreases the liver plasma membrane $\mathrm{Ca}$ ATP-ase activity in intact rats (Yamaguchi, 1979), increases the uptake of calcium by the liver cells and inhibits the efflux of calcium to the extracellula from the intracellula (Yamaguchi and Yamamoto, 1976). Presumably CT increases the calcium in the liver cells by both stimulating calcium influx and inhibiting calcium efflux in the liver cells, and thus causes a remarkable elevation of calcium excretion into the bile.

From the present work, it is assumed that the endogenous CT, secreted by the elevation of serum calcium, accumulates the serum calcium into the liver, and then excretes the liver calcium into the bile. CT plays an important role in the control of calcium homeostasis in the serum by regulating the calcium metabolism in the hepatic bile system of rats.

\section{References}

Broulik, P. D. and V. Pocorsky (1973). Endocrinol. Exp. 7, 183.

Chambaut, A. M., F. Leray-Pecker, G. Feldmann and J. Hanoue (1974). J. Gen. Physiol. 64, 104.

Forte, J. G., T. M. Forte and H. Henz (1973). Biochem. Biophys. Acta 298, 827.

Haas, H. G., M. A. Dambacher and J. Gunvaga (1971). J. Clin. Invest. 50, 2689.

Johnston, C. C. Jr. and W. P. Deiss Jr. (1966). Endocrinology 78, 1139.

Lowry, O. H., N. J. Rosebrough, A. L. Farr and R. J. Randall (1951). J. Biol. Chem. 194, 265.

Moore, L., D. F. Fitzpatrick, T. S. Chen and E. J. Landon (1974). Biochim. Biophys. Acta 345, 405.

Nakamura, M. and K. Mori (1958). Nature (London) 182, 1141.

Olson, E. B. Jr., H. F. DeLuca and J. T. Potts Jr. "Calcium, Parathyroid Hormone and Calcitonins,", (ted. by R. V. Talmage and P. L. Munson), Excerpta Medica, Amsterdam, p. 240 (1972).

Robert, R. J., C. D. Klaassen and G. L. Plaa (1967). Proc. Soc. Exp. Biol. Med. 125, 313.

Willis, J. B. (1960). Nature (London) 16, 249.

Yamaguchi, M. (1978). Endocrinol. Japon. 25, 533.

Yamaguchi, M. (1979). Ibid. 26, 605.

Yamaguchi, M., Y. Takei and T. Yamamoto (1975). Endocrinology 96, 1004.

Yamaguchi, M. and T. Yamamoto (1976). Chem. Pharm. Bull. (Tokyo) 24, 159.

Yamaguchi, M. and T. Yamamoto (1978). Ibid. (Tokyo) 26, 1981.

Yamaguchi, M. and T. Yamamoto (1979). Ibid. (Tokyo) 27, 1671. 